\title{
CORE SELF-EVALUATION AND JOB SATISFACTION: MEDIATING ROLE OF CAREER COMMITMENT
}

\author{
Meily Sutanti, Christine Winstinindah Sandroto \\ Atma Jaya Catholic University of Indonesia
}

\begin{abstract}
This study aims to determine the effect of core self-evaluation on job satisfaction mediated by career commitment in IBM-JTI employees. The sampling technique was convenience sampling using 86 samples. This research's data analysis method is the mediation test using the PreacherHayes The Simple Mediation Model. The data processing was done using SPSS 22 for windows with macros and syntax. This study's results indicate that core self-evaluation and career commitment have a direct effect on job satisfaction. The effect of core self-evaluation on job satisfaction is not mediated by career commitment. Core self-evaluation does not affect career commitment.
\end{abstract}

Keywords: core self-evaluation, career commitment, job satisfaction

\section{INTRODUCTION}

Tardiness, employee complaining, disobedience, avoidance of partial job responsibilities, or resignation can express employee dissatisfaction. Central Bureau of Statistics shows a high unemployment rate in Indonesia, as much as 7.07 percent (www.bps.go.id, 2020). Job dissatisfaction has a severe impact on decreasing work productivity to a downward career path and indirectly affects the number of unemployment. According to Herzberg (Robbins \& Judge, 2017), the factors influencing job dissatisfaction are working conditions, supervision, salary, job security, and status. Meanwhile, the factors that influence job satisfaction are achievement, responsibility, recognition, progress, and growth. Job satisfaction is negatively related to employee absence and turnover, but it is the organization's responsibility to reward its employees. Job satisfaction can be obtained in various ways, both from the organization and from oneself. One way

\footnotetext{
*Corresponding Author.

e-mail: e-mail: christine.wins@atmajaya.ac.id
} 
to find job satisfaction to keep doing self-evaluation positively. By conducting evaluations and assessments, the organization can determine the extent of the organization's capabilities, strengths and weaknesses, and these become determinants for the next steps to be taken by the organization. Superiors carry out evaluations towards subordinates, but it is also necessary to evaluate ourselves to see the extent of our abilities, progress, and our role in the organization.

Individuals have different views on whether they like or dislike themselves and whether they consider themselves as capable and effective. This selfperspective is a concept of core self-evaluation. Individuals with positive core self-evaluations who like themselves consider themselves effective, proficient, and in control of their environment. Meanwhile, individuals with negative core self-evaluations tended to dislike themselves, doubt their abilities, and consider themselves powerless over their environment" (Robbins \& Judge, 2017). Core self-evaluation is a model of individual personality that influences a person's motivation and performance. This core self-evaluation shows its influence on individual behavior at work. Individuals with positive core self-evaluations will perform better because they set more ambitious, committed goals and last longer trying to achieve these goals. The core self-evaluation personality model is essential to study because it can understand and predict a person's work attitude and behavior (Judge and Bono, 2001).

Having a positive attitude towards oneself is not enough to have the expected job satisfaction. Still, both individuals and organizations need to increase work commitment to spur their motivation to work and achieve organizational goals. According to Konopaske, Ivancevich, \& Matteson (2018), commitment to the organization and the team is where a person is positively related to "willingness to help" and adapting to events that could not know beforehand.

PT Jasa Teknologi Informasi IBM, known as IBM-JTI, is a wholly-owned subsidiary of PT IBM Indonesia. IBM-JTI was established to support IBM in providing skilled install-move-add-change (IMAC) and to carry out other activities related to "after sales support" for IBM products in Indonesia. IBM has the vision to be an information technology service provider that is favored and recognized as a significant contributor to their clients. Achieving this vision requires cooperation from all employees who have the abilities and capabilities 
important to the company. To maintain existing resources, some of the strategies that IBM-JTI undertake are increasing job satisfaction by providing salaries above the minimum wage, bonuses, a comfortable workplace, a friendly work environment, and providing support to employees through training on an ongoing basis. The strategy used by the company in maintaining the existing critical resources has proven successful because until now, it has been able to maintain IBM-JTI to become the leading information technology service provider in Indonesia. Apart from the company's effort in increasing employee job satisfaction, other factors in the employee's personality can also increase job satisfaction. Therefore, to find out other factors in the employee's personality that can increase job satisfaction, the researcher chose IBM-JTI as a research object because the IBM-JTI could run its company well and in a stable manner as well as providing satisfaction to its employees. These things give urgency to examine the effect of core selfevaluation on job satisfaction with the mediator of career commitment.

\section{LITERATURE REVIEW}

\subsection{Job Satisfaction}

Robbins \& Judge (2017) stated that job satisfaction is a positive feeling about one's job, which results from an evaluation of its characteristics. A person with a high level of job satisfaction has a positive attitude towards their job, while a person who is not satisfied with their job will have a negative attitude towards their job. Job satisfaction describes employees' feelings or affective states of employees about their work, and an assessment of the job or work situation is considered the most appropriate (Wright, Cropanzano, \& Bonett, 2007). Job satisfaction is a negative or positive feeling of employees on their job (Woo, Jerrold, \& Leong, 2005). On the one hand, job satisfaction is an independent variable that impacts dependent variables such as return, absenteeism, turnover, service leaving, individual behavior in society, individual behavior in the family, and the social, cultural, and political environment (Hunjra et al., 2010). Research shows that people who tend to be positive and cheerful often tend to express higher job satisfaction than people who tend to be moody and gloomy (Greenberg, 2011). According to Kreitner \& Kinicki (2012), five factors affect job satisfac- 
tion: need fulfilment, discrepancies, value attainment, equity, and genetic components. Besides, there are also determinants of job satisfaction, including the work itself, supervision, co-workers, promotion, and pay.

The relationship between job satisfaction and other variables can be positive or negative. Correlation ranges from weak to strong. According to Kreitner \& Kinicki (2012), a strong relationship shows that superiors can significantly influence other variables by increasing job satisfaction. Several correlations of job satisfaction are as follows: between motivation and job satisfaction there is a positive and significant relationship; job involvement has a relationship with job satisfaction, and the role of superiors /managers needs to be encouraged to strengthen a satisfying work environment to increase employee work involvement; there is a significant and robust relationship between organizational commitment and satisfaction because increased job satisfaction will lead to a higher level of commitment; between absence and satisfaction there is a strong negative correlation; the relationship between turnover and satisfaction is negative; feeling of stress with job satisfaction shows a negative relationship where the increase in job satisfaction will reduce the negative impact of stress, and there is a positive relationship between satisfaction and performance.

\subsection{Core Self-Evaluation}

The core self-evaluation concept is that individuals have different views on whether they like or dislike themselves and whether they consider themselves proficient and effective (Robbins \& Judge, 2017). Individuals with high core selfevaluations will be more effective in overcoming obstacles by using better problem-solving strategies to minimize stress. Individuals with this personality trait will have higher motivation to do a job. These individuals will do a better job because they have increased confidence in their abilities. They are also able to understand and predict attitudes and work behavior of a person (Judge \& Bono, 2003).

Judge \& Bono (2001) stated that core self-evaluations consist of four personality traits: locus of control, emotional stability, self-esteem, and selfefficacy. Locus of control is the extent to which a person can control the events that occur to him (Robbins \& Judge, 2017). These personality traits are 
Meily Sutanti, Christine Winstinindah Sandroto / Core Self-Evaluation and Job Satisfaction: Mediating Role of Career Commitment

associated with various essential job outcomes, including job satisfaction and performance (Judge and Bono, 2001). Locus of control is a core self-evaluation indicator because individuals who think they have less control over their lives tend to have less self-confidence. A person with low emotional stability will tend to have unstable emotions and be overwhelmed by negative feelings, such as anxiety, sadness, irritability, and nervousness (Pervin \& John, 2001). Individuals with high emotional stability are individuals who can maintain their emotional balance. Individuals with this characteristic have an evenness of mood, high optimism, cheerfulness, calm, free from guilt, worry, or loneliness (Chaturvedi \& Chander, 2010).

Self-esteem is the extent to which a person sees himself as capable and worthy of doing a job (Judge and Bono, 2003). Self-esteem includes two aspects, namely self-acceptance, and self-respect (Rahmania \& Yuniar, 2012). The higher self-esteem, a person will see himself as valuable, capable, and acceptable (Kreitner \& Kinicki, 2012). It is easy to see why self-esteem reflects core selfevaluation; individuals who have a favorable view of themselves and their abilities tend to like themselves and consider themselves valuable. Individuals with low self-esteem levels are more susceptible to external influences, suggesting that this type of individual is dependent on receiving positive evaluations from other individuals. (Robbins \& Judge, 2017).

Self-efficacy can be described as the belief that an individual has to act successfully and achieve a specific result. Individuals with high self-efficacy will be diligent in doing something, have fewer doubts, carry out activities and seek new challenges (Damayanti, Wirakusuma, \& Wirama, 2015).

\subsection{Employee Commitment}

Muthuveloo \& Rose (2005) stated that commitment is described as a level of employee engagement in several aspects. Employee commitment can help various parties build an understanding of employee's attitudes and behavior in an organization. Employment commitment can be classified into three (3) groups, namely: work/job commitment, career/professional commitment, and organizational commitment, as seen in Figure 1. 


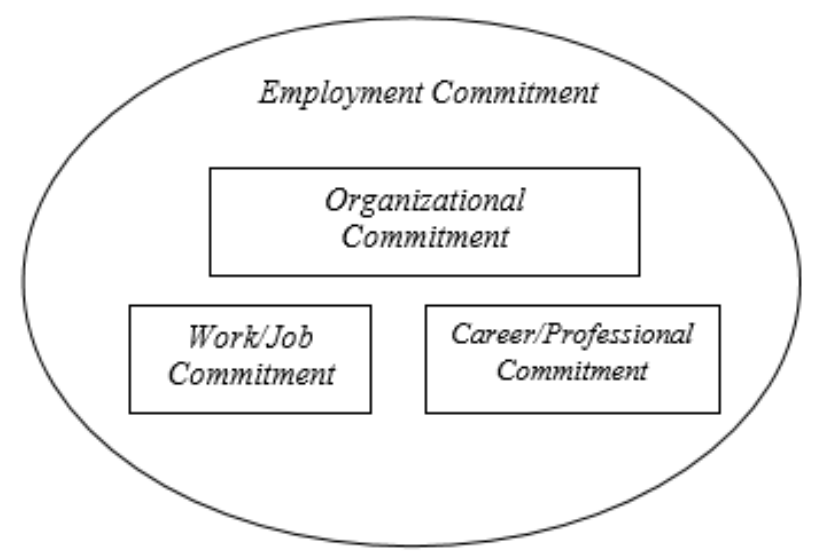

Figure 1 Typology of Employee Commitment

Source: Meyer \& Lynne (Muthuveloo \& Rose, 2005)

Organizational commitment reflects a "multidimensional psychological attachment" from individuals to the organization. There are two (2) dominant concepts regarding organizational commitment in the sociological literature: loyalty and intention to stay. Job commitment refers not to the organization or one's career but to the job itself (Muthuveloo \& Rose, 2005). A person who feels attached to work has a strong sense of duty or obligation to his job and places his work's intrinsic value as a "central life interest."

\subsection{Career Commitment}

Career commitment is defined as a motivating force to work in the chosen career role (Adekola, 2011). Career commitment refers to identification with, and involvement in, one's position (Muthuveloo \& Rose, 2005). Another term, career commitment, include occupational commitment and professional commitment. So generally defined as feeling tied to one's career, or position, compared to the organization that employs them. Career commitment indicates the variable attitude of employees towards their work (Myrtle et al., 2011). It describes the employee's willingness or desire to keep their jobs and realize personal career goal development and identification with and involvement in those goals. A more positive acceptance of a job makes individuals more willing to take responsibility and achieve work goals (Myrtle et al., 2011). 
Career commitment is a component of the career dimension, which is defined as a concept that affects job relationships to overcome dissatisfaction in the search for career goals. A person who shows a career commitment can persist in pursuing career goals, even in the face of obstacles and setbacks. The existence of a career commitment reflects the work commitment they have and links it to the desired career results. Someone who has a strong commitment will generate high enthusiasm for the completion of tasks and jobs so that they can make efforts to achieve career advancement (Ballout, 2009).

According to Allen and Meyer (Myrtle et al. 2011), commitment can also mean a strong acceptance of the individual towards the organization's goals and values. Individuals strive, work and have a strong desire to remain in the organization. Allen and Meyer said that career commitment includes: liking the job itself (affective commitment), evaluating the cost of job changes (continuous commitment), and concern about breaking social rules caused by job changes (normative commitment).

A person committed to a career will not be easily defeated by the challenges that he/she faces. Differences in attitudes, individual and situational circumstances at work are an essential element of career commitment. Career commitment is said to be positive if an employee can show a high interest in learning, increasing his knowledge, and sharing his knowledge with others (Ballout, 2009). A career is a lifelong process consisting of a sequence of activities and related attitudes or behaviors that occur in a person's life. It is also viewed as a pattern of work-related experiences (such as job positions, job assignments or activities related to the decision to work, and subjective interpretations of work-related events) (Adekola, 2011).

\subsection{Career Development}

Career development is an on-going process of an individual through a series of levels where in each level the character develops unique characteristics, either from the main problem or the assigned task (Adekola, 2011). Career development describes the individual's perceptions in an organization about the development of organizational members (employees) at a level that can be achieved during a particular work period. According to Erdogen (Barnett \& Bradley, 
2007), organizations must find creative ways to overcome attraction, motivation, and retention challenges. Organizations can meet these challenges is by supporting employees to develop their careers and increase career satisfaction. Meanwhile, career reflects the development of the organization's members, in this case, employees, in positions or ranks that can be achieved during their tenure in the organization concerned.

\subsection{Effect of Core Self-Evaluation on Job Satisfaction}

Core self-evaluation literature supports a strong relationship between core self-evaluation and job satisfaction (Judge \& Bono, 2001). Both cross-sectional and longitudinal studies found that people who have a high level of core selfevaluation will allow them to feel satisfied with their work. For example, in a study analyzing three different samples, Judge \& Bono (2001) found that the coefficient correlation between job satisfaction and core self-evaluation was significant.

Hypothesis 1: Core self-evaluation has a significant effect on job satisfaction

\subsection{Effect of Career Commitment on Job Satisfaction}

Career commitment is considered a significant independent variable for job satisfaction. Individuals with low career commitment will rarely spend a lot of energy or set high goals at work. Thus they will get less out of their work, which significantly exacerbates their psychological dissatisfaction (Zelenski, Murphy, \& Jenskin, 2008).

Career commitment is positively correlated with job satisfaction (Goulet \& Singh, 2002). They find that when employees are satisfied with the nature of the job, they are satisfied with their supervisors and co-workers themselves, perceive a sufficient salary policy, and have a chance of getting a promotion in the future. They will generally be satisfied with their job so that a high career commitment is to be expected.

Hypothesis 2: Core self-evaluation has a significant effect on career commitment. 


\subsection{Effect of Core Self-Evaluation on Job Satisfaction with Career Commitment Mediators}

In the development of positive psychology, there is increasing attention to subjective well-being, an affective and cognitive evaluation of life happiness and satisfaction (Zhang et al., 2013). Many studies say that job satisfaction is positively related to subjective well-being (Zhang et al., 2013). As an essential indicator of subjective well-being in the workplace, job satisfaction has become a vital role in career and adult life. Many studies have shown that personality variables such as core self-evaluation, optimism, other positive emotional experiences, and attitude variables such as career commitment and organizational commitment can significantly predict a person's job satisfaction level (Bowling, Hendricks, \& Wagner, 2008).

Self-evaluation, commitment to work, and job satisfaction are factors that will affect a person's attitude at work. Several researchers on employee commitment have been conducted. Dormann et al. (2006) examined "A State-Trait Analysis of Job Satisfaction: On the Effect of Core Self-Evaluations." This study deals with (a) the relationship between the variance of job satisfaction and the core self-evaluation and (b) the structure of the core self-evaluation variables. The results showed only negative affectivity and internal locus of control, which significantly impacted job satisfaction, while self-esteem and self-efficacy did not.

Xiao et al. (2014) did a study on "Effects of person-vocation fit and core self-evaluation on career commitment of medical university students: the mediator roles of anxiety and career satisfaction." Their research shows that core selfevaluation can significantly predict continuance and normative commitment where anxiety and career satisfaction act as mediators.

Peng \& Mao (2015) researched "The Impact of Person-Job Fit on Job Satisfaction: The Mediator Role of Self Efficacy." This study shows a significant correlation between person-job fit and self-efficacy with job satisfaction. Kong, Cheung, \& Song (2012) conducted a study on "Determinants and Outcome of Career Competencies: Perspectives of Hotel Managers in China." The results found that the organization's career management and career commitment have positive results, meaning that they directly affect career competencies and career satisfaction. 
Zhang et al. (2013) examined the impact of Core Self-evaluation on Job Satisfaction with the mediating role of Career Commitment. Their research proves that core self-evaluation, job satisfaction, and career commitment correlate with each other. Core self-evaluation has a positive relationship with job satisfaction, meaning that when the core self-evaluation results are high, the level of job satisfaction is also high. Besides, the relationship between core selfevaluation through career commitment to job satisfaction shows significant results.

Hypothesis 3: Career commitment has a significant effect on job satisfaction

Hypothesis 4: Core self-evaluation significantly affect job satisfaction with career commitment as a mediating variable.

\section{RESEARCH METHODS}

\subsection{Participants and Procedure}

The population in this study were all 400 employees at IBM-JTI, Jakarta. Samples were calculated using the Slovin formula (Umar, 2003), and the results were 80 respondents. These results do not make the researchers collect a sample of 80 samples, but rather make the calculation results of the sample as a minimum sampling, where the number of samples taken is 86 . Sampling in this study used a non-probability sampling method, with data collection using a convenience sampling technique, namely sampling based on the availability of elements and the ease of obtaining them (Noor, 2011).

Measurement of job satisfaction variables used the Minnesota Satisfaction Questionnaire instrument developed by Weiss et al. (Jiaxi Zhang et al., 2013), consisting of nineteen (19) items that measure job satisfaction. Respondents will describe the level of satisfaction using a Likert scale, in the range of 1-5, which are very dissatisfied $($ score $=1)$ to very satisfied $($ score $=5)$. The instrument used to measure core self-evaluation in this study was The Core Self-Evaluation Scale, developed by Judge et al. (2003), consisting of twelve (12) items. The core selfevaluation questionnaire has a Likert scale of 1-5, from strongly disagree $($ score $=1)$ to strongly agree $($ score $=5)$. Meanwhile, the instrument used to 
measure career commitment in this study was the Chinese Career Commitment Scale (CCCS) instrument. CCCS was developed by Long (Zhang et al., 2013) based on the "Three Factors Theory" in the career commitment proposed by Meyer et al. (1993, in Zhang et al., 2013), consisting of eight items. The questionnaire regarding career commitment has a Likert scale range of 1-5, from a strongly disagreeable $($ score $=1)$ to a strongly agree $($ score $=5)$.

\section{RESULTS AND DISCUSSION}

In this study, the reliability test, validity test, descriptive statistics, $\mathrm{p}$ plots normality test, average value analysis, and Preacher Hayes analysis were performed. Validity and reliability test results show the scale to be valid and reliable.

Based on the validity test, all items were valid. Proved the p-value of each variable $<0.05$. The core self-evaluation correlation coefficient is between 0.393 0.641 ; job satisfaction ranges from 0.450-0.805; and career commitment between $0.579-0.840$.

Cronbach's Alpha for core self-evaluation: 0.705; job satisfaction: 0.923; and career commitment: 0.869 , all of which are greater than the reliability requirements, a minimum Cronbach's Alpha of 0.7. So all of these variables are reliable. The data processed is normally distributed so the normality test is fulfilled.

\section{Descriptive Statistics}

Table 1 Demographic Respondent

\begin{tabular}{lcc}
\hline & Frequency & Percentage \\
\hline Gender & & \\
Male & 31 & 36.05 \\
Female & 55 & 63.95 \\
Total & 86 & 100 \\
\hline Age & & \\
$20-29$ & 69 & 80.23 \\
$30-39$ & 15 & 17.44 \\
$40-49$ & 2 & 2.33 \\
Total & 86 & 100 \\
\hline
\end{tabular}




\begin{tabular}{lcc}
\hline Education & & \\
Senior high school & 4 & 4.65 \\
Diploma & 10 & 11.63 \\
Undergraduate degree & 70 & 81.40 \\
Postgraduate degree & 2 & 2.32 \\
Total & 86 & 100 \\
\hline Number of years & & \\
working & & \\
$<1$ & 37 & 43.00 \\
1 & 23 & 26.70 \\
2 & 6 & 7.00 \\
$>3$ & 20 & 23.30 \\
Total & 86 & 100 \\
\hline
\end{tabular}

There were 86 respondents, the majority of respondents were female (63.95\%), the age range was $20-29$ years old (80.23\%), the latest education was at the undergraduate level $(81.40 \%)$. In comparison, the working period was less than one year (43.0\%).

\section{Mean Score}

Overall mean score core self-evaluation is high (mean $=3.61$ ); job satisfaction is high (mean $=3.72)$; and career commitment is high (mean=3.73).

\section{Hypothesis test}

Table 2 Total Effect of Core Self-Evaluation on Job Satisfaction (c path)

\begin{tabular}{cccccc}
\hline & Coeff & se & t & R-sq & p \\
\hline Core Self-Evaluation & 0,5340 & 0,1894 & 2,8200 & 0,0865 & 0,0060 \\
\hline
\end{tabular}

Based on the table above, we can conclude that the core self-evaluation variable significantly affects job satisfaction $(\mathrm{R}$ square $=0.0865$, Sig. Value $(0.006)<0.05$. Thus hypothesis 1 is accepted.

Table 3 Effect of Independent Variable Core Self-Evaluation on Mediator Career Commitment (a path)

\begin{tabular}{cccccc}
\hline & Coeff & se & t & R-sq & p \\
\hline Core Self-Evaluation & 0,1413 & 0,0915 & 1,5451 & 0,0276 & 0,1261 \\
\hline
\end{tabular}


Meily Sutanti, Christine Winstinindah Sandroto / Core Self-Evaluation and Job Satisfaction: Mediating Role of Career Commitment

Based on Table 3, the core self-evaluation variable does not significantly affect career commitment with the Sig value. $(0.126)>0.05$. Hypothesis 2 is rejected.

Table 4 Direct Effect Mediators (Career Commitment) on Dependent Variable (Job Satisfaction) - b path

\begin{tabular}{cccccc}
\hline & Coeff & se & t & R-sq & p \\
\hline Career Commitment & 1,2798 & 0,1786 & 7,1664 & 0,4357 & 0,0000 \\
\hline
\end{tabular}

Information from Table 4 states that the career commitment variable significantly affects job satisfaction ( $\mathrm{R}$ square $=0.4357$, Sig. value $(0,000)<$ 0.05. Hypothesis 3 is accepted.

Table 5 Direct Effect Core Self-Evaluation on Job Satisfaction (c 'path)

\begin{tabular}{ccccc}
\hline & Effect & se & $\mathbf{t}$ & $\mathbf{p}$ \\
\hline Core Self-Evaluation & 0,3531 & 0,1518 & 2,3255 & 0,0225 \\
\hline
\end{tabular}

Based on Table 5, we know that the core self-evaluation variable significantly affects job satisfaction directly because of Sig. value $(0.0225)<0.05$.

Table 6 Indirect Effect Core Self-Evaluation on Job Satisfaction with Career Commitment as a Mediators (ab)

\begin{tabular}{ccccc}
\hline & Effect & se & Z & p \\
\hline Career Commitment & 0,1809 & 0,1209 & 1,4966 & 0,1345 \\
\hline
\end{tabular}

From Table 6, we can conclude that career commitment does not mediate the effect of core self-evaluation on job satisfaction (Sig. Value $(0.1345)>0.05$. Thus, hypothesis 4 is rejected.

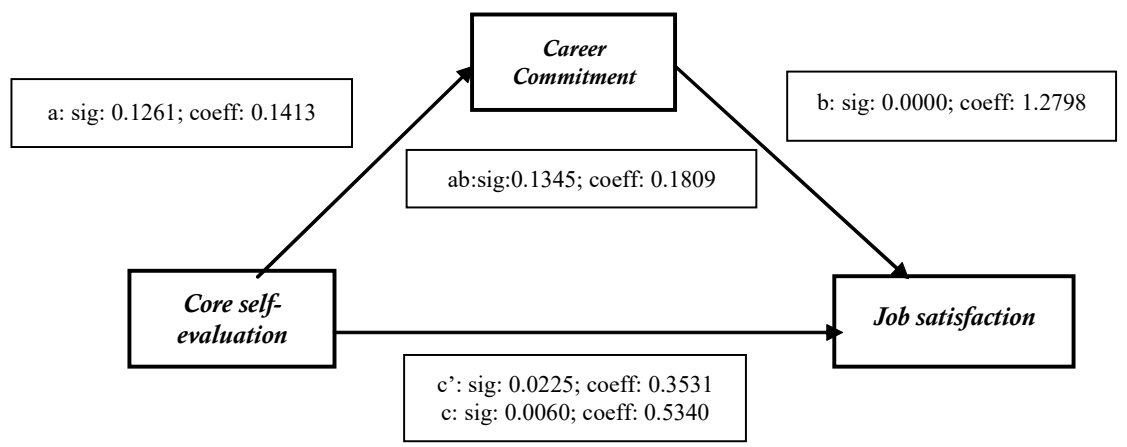

Figure 2 Summary of Hypothesis Testing 
The figure above shows that the indirect effect of core self-evaluation on job satisfaction through the mediator commitment $(\mathrm{ab})$ has no significant effect with Sig. value $(0.1345)>0.05$.

There is a significant influence between core self-evaluation as an independent variable and job satisfaction as the dependent variable on IBM-JTI employees. This finding supports the theory that people who have a high level of core self-evaluation will be satisfied with their work (Judge \& Bono, 2001). Also, research conducted by Zhang et al. (2013) stated that core self-evaluation has a positive relationship with job satisfaction, meaning that when core self-evaluation results are high, the level of job satisfaction is also high.

In this study, the core self-evaluation variable did not significantly affect the career commitment variable for IBM-JTI employees. These results contradict research conducted by Zhang et al. (2013), which shows a positive relationship between core self-evaluation and career commitment. According to the authors, the results showing the insignificant influence between core self-evaluation and career commitment can be caused by career commitment, which may not be a mediating variable but rather a suppressor variable or a moderating variable. Wherewith the moderation of the career commitment variable may increase the effect of core self-evaluation on job satisfaction. This insignificant result could also occur due to differences in the respondents' characteristics from the previous study. The previous study used the army in China as respondents from non-profit organizations and had a different organizational culture from IBM-JTI employees who have the autonomy to do their job, flexible work hours, and get bonuses and rewards above the minimum wage.

There is a significant influence between the mediation variable, career commitment, and the dependent variable, job satisfaction. These results support the study by Zelenski, Murphy, \& Jenkins (2008) that career commitment is essential for job satisfaction.

Individuals with low career commitment will rarely spend a lot of energy or set high goals at work. It will have fewer returns from their work, which significantly exacerbates their psychological dissatisfaction. This hypothesis' significant results also support a previous study by Kong, Cheung, \& Song (2012) and Zhang et al. (2013), which stated that career commitment has a positive relationship with job satisfaction. 
Meily Sutanti, Christine Winstinindah Sandroto / Core Self-Evaluation and Job Satisfaction: Mediating Role of Career Commitment

This study shows the insignificant results of core self-evaluation on job satisfaction through the mediator career commitment to IBM-JTI employees. This study's results are not following previous research conducted by Zhang et al. (2013), which states that the relationship between core self-evaluation through career commitment to job satisfaction shows significant results. The cause of this insignificant result, according to the author, is the same as why hypothesis 2 was rejected, namely because of the possible role of career commitment not as an intervening variable and differences in respondent characteristics used by the author and previous researchers.

Hypothesis 2 and hypothesis 4 show insignificant results between the core self-evaluation and career commitment and the effect of core self-evaluation on job satisfaction with the mediator career commitment on IBM-JTI employees. However, hypothesis 1 and hypothesis 3 show significant results on the direct effect of core self-evaluation and career commitment on job satisfaction among IBM-JTI employees. These results indicate that the core self-evaluation variable can directly impact job satisfaction without the mediating variable. Likewise, this variable can act as an independent variable on the career commitment variable that can directly impact job satisfaction.

This study's implication is that core self-evaluation and career commitment are positively related to job satisfaction. This result is evidenced by the core selfevaluation and career commitment tests, which have a p-value $<0.05$, which means a significant effect on job satisfaction. Career commitment has an R-sq of $43.57 \%$ on job satisfaction, while core self-evaluation has an R-sq of $8.65 \%$. These results indicate that the job satisfaction level variability can be explained more by the career commitment variable than the core self-evaluation variable.

The direct effect of core self-evaluation and career commitment on job satisfaction shows that increasing core self-evaluation or career commitment can increase job satisfaction. The IBM-JTI company can increase job satisfaction IBM - JTI employees by improving employee core self-evaluation and career commitment. The higher the core self-evaluation and career commitment will increase employee job satisfaction.

IBM-JTI employees have high levels of core self-evaluation, career commitment, and job satisfaction with overall mean scores of 3.61, 3.72, and 3.73, respectively. However, several dimensions of core self-evaluation and job satisfac- 
tion are at a moderate level and need improvement, such as dimensions of emotional stability and satisfaction with salaries. IBM-JTI, which was founded in 2003, has skilled human resources and is equipped with supporting technology. Achieving company goals requires assistance and cooperation from all employees who have critical abilities and capabilities for the company.

IBM - JTI has implemented several strategies to increase job satisfaction. The strategy implemented is to provide bonuses, a comfortable workplace, a friendly work environment, and support through training. Based on the author's research, there are other ways to increase job satisfaction, namely by increasing the value of core self-evaluation and career commitment. The company needs to pay attention to core self-evaluation and career commitment because the higher the core self-evaluation and career commitment, the higher the level of employee job satisfaction.

Providing self-motivation training can improve core self-evaluation. This training will make employees have positive beliefs, appreciate and reward what they have achieved, provide HR consultants for employees to help employees control emotions, solve existing problems so as not to hinder the work of the company, and provide entertainment for employees to reduce their boredom. Emotional stability needs to be of particular concern to the company because based on the data analysis conducted, the emotional stability of IBM - JTI employees is in a suitable category, so that it needs to be improved.

Giving employees the freedom to express opinions, involve or give job responsibility, hold a mentoring or consultation program where employees can learn to improve their capabilities and determine their career path can enhance career commitment.

\section{CONCLUSION}

This study concluded that core self-evaluation has a significant effect on job satisfaction. Core self-evaluation has no significant effect on career commitment. Career commitment has a significant effect on job satisfaction, and career commitment does not mediate the effect between core self-evaluation and job satisfaction. This conclusion implies that to improve job satisfaction, IBM-JTI 
Meily Sutanti, Christine Winstinindah Sandroto / Core Self-Evaluation and Job Satisfaction: Mediating Role of Career Commitment

must improve core self-evaluation and employee career commitment. It is proven that the higher the core self-evaluation and career commitment, the higher the job satisfaction. Further intervention can be carried out on several core selfevaluation and career commitment items whose average value has not yet reached a high level to be improved.

\section{REFERENCES}

Adekola, Bola. (2011). Career Planning and Career Management as Correlates For Career Development and Job Satisfaction: A Case Study of Nigerian Bank Employees. Australian Journal of Business and Management Research, 1(2), 100-112.

Ballout, Hassan I. (2009). Career Commitment and Career Success: Moderating Role of Self Efficacy. International Journal of Career Development, 14(27), 655-670.

Barnett, B. R. \& Bradley, L. (2007). The Impact of Organisational Support for Career Development on Career Satisfaction. Career Development International, 12(7), 617-636.

Bowling, N., Hendricks, E., \& Wagner, S. (2008). Positive and Negative Affectivity and Facet Satisfaction: A Meta-Analysis. Journal of Business and Psychology, 23(3), 115-125.

Chaturvedi, M. \& Chander, R. (2010). Development of Emotional Stability Scale. Industrial Psychiatry Journal, 19, 37-40.

Damayanti, N. N. S. R., Wirakusuma, M. G., \& Wirama, D. G. (2015). Pengaruh Core Self Evaluation Pada Kinerja Auditor Badan Pemeriksa Keuangan Republik Indonesia Perwakilan Provinsi Bali. E-Jurnal Ekonomi dan Bisnis Universitas Udayana. 4.05, 361-380.

Dormann, C., Fay, D., Zapf, D., \& Frese, M. (2006). A State-Trait Analysis of Job Satisfaction: On the Effect of Core Self-Evaluations. Applied Psychology: An International Review, 55(1), 27-51.

Goulet, L. \& Singh, P. (2002), Career Commitment: a Reexamination and Extension, Journal of Vocational Behavior, 61, 73-91.

Greenberg, Jareld. (2011). Behavior Organizations. 10 ed. Pearson Education. 
Hunjra, A., Chani, M., Sher, A., Azam, M., \& Kashif-Ur-Rehman. (2010). Factors Affecting Job Satisfaction of Employees in the Pakistani Banking Sector. Afr. J. Bus. Manag., 4(10), 2157-2163.

Judge, T. A. \& Bono, J. E. (2001). Relationship of Core Self-Evaluations Traits With Job Satisfaction and Job Performance: A Meta-Analysis. Journal of Applied Psychology, 86, 80-92.

Judge, T. A. \& Bono, J. E. (2003). Core Self Evaluations: A Review of the Trait and its Role in Job Satisfaction and Job Performance. European Journal of Personality, 17, 5-8.

Judge, T. A., Erez, A., Bono, J. E., \& Thoresen, C. J. (2003). The core selfevaluations scale: Development of a measure. Personnel Psychology, 56, 303-333.

Kong, H., Cheung, C., \& Song, H. (2012). Determinants and Outcome of Career Competencies: Perspectives of Hotel Managers in China, International Journal of Hospitality Management, 31, 3, 712-719.

Konopaske, R., Ivancevich, J. M., \& Matteson, M. T. (2018). Organizational Behavior and Management, 11 ed. McGraw Hill Int.

Kreitner, R. \& Kinicki, A. (2012). Organizational Behavior. 10ed. Irwin/McGrawHill.

Muthuveloo, R. \& Rose, R.C. (2005). Typology of Organizational Commitment. American Journal of Applied Science, 2(6), 1078-1081.

Myrtle, R., Duan-Rung Chen, Caroline Liu, \& Fahey, D. (2011). Job and Career Influences on the Career Commitment of Health Care Executives: The Mediating Effect of Job Satisfaction. Journal of Health Organization and Management, 25, 693-710.

Noor. (2011). Metodologi Penelitian. Jakarta: Kencana.

Peng, Y., \& Mao, C. (2015). The Impact of Person-Job Fit on Job Satisfaction: The Mediator Role of Self Efficacy. Social Indicator Research, 121, 805813.

Pervin, L.A. \& John, O.P. (2001). Personality: Theory and Research, 8ed. John Wiley \& Sons, Inc.

Rahmania, P. N. \& Yuniar, I. C. (2012). Hubungan Antara Self-Esteem dengan Kecenderungan Body Dysmorphic Disorder Pada Remaja Putri. Jurnal Psikologi Klinis dan Kesehatan Mental, 1, 110-117. 
Meily Sutanti, Christine Winstinindah Sandroto / Core Self-Evaluation and Job Satisfaction: Mediating Role of Career Commitment

Robbins, S. P. \& Judge, T. (2017). Organizational Behavior .17 ed.. Upper Saddle River, N.J.: Pearson International Edition.

Umar, H. (2003). Metode Riset Bisnis: panduan mahasiswa untuk melaksanakan riset dilengkapi contoh proposal dan hasil riset bidang manajemen dan akuntansi. Jakarta: PT Gramedia Pustaka Utama.

Woo, GK., Jerrold, K., \& Leong, YKL. (2005) Effect of Service Orientation on Job Satisfaction, Organizational Commitment, and Intention of Leaving in a Casual Dining Chain Restaurant. J. Hosp. Manag., 24, 171-193.

Wright, T. A., Cropanzano, R., \& Bonett, D. G. (2007). The Moderating Effects of Employee Positive Well Being in the Relation between Job Satisfaction and Job Performance. Journal of Occupational Health Psychology, 12, 93104.

Xiao W., Zhou L., Wu Q., Zhang Y., Miao D., Zhang J., Peng J. (2014). Effects of Person-Vocation Fit and Core Self-evaluation on Career Commitment of Medical University Students: the Mediator Roles of Anxiety and Career Satisfaction. International Journal of Mental Health Systems. 20;8:8, 1-6.

Zhang, J., Wu, Q., Miao, D., Yan, X., \& Peng, J. (2013). The Impact of Core Self-evaluations on Job Satisfaction: The Mediator Role of Career Commitment. Social Indicator Research, 116, 809-822.

Zelenski, J. M., Murphy, S. A., \& Jenkins, D. A. (2008). The Happy-productive Worker Thesis Revisited. Journal of Happiness Studies, 9, 521-537.

Website:

https://www.bps.go.id/pressrelease/2020/11/05/1673/agustus-2020—tingkatpengangguran-terbuka-tpt-sebesar-7-07-persen.html (accessed 13 February 2021). 
Review of Management and Entrepreneurship

Volume 05, Number 02, October 2021 